\title{
Water balance for pomegranate based on meteorological data
}

\section{R.V. SHINDE, S.B. JADHAV AND S.N. PAWAR}

See end of the Paper for authors' affiliation

Correspondence to :

\section{R.V. SHINDE}

Department of Basic Science and Computer Technology, College of Agriculture Engineering and Technology, Vasantrao Naik Marathwada Krishi Vidyapeeth, PARBHANI (M.S.) INDIA

Email : patil.ravi4590@ gmail.com
-ABSTRACT : Water balance of an area is an itemized statement of all gains, losses and changes of storage of water occurring in a given field within specified boundaries during aspecified period of time considering rainfall and evapotranspiration. Difference between rainfall $(\mathrm{P})$ and pomegranate evapotranspiration $\left(\mathrm{ET}_{\mathrm{p}}\right.$ ) gives weekly moisture excess and deficit.A negative value of this difference indicates water deficit, which means the amount by which the rainfall fails to supply the potential water need of tree. While positive difference is water excess, this is the amount of excess water available for soil moisture replenishment and also for a runoff. Weekly rainfall and evapotranspiration data of both the districts were analyzed statistically for Ambie, Mrig and Hasta bahar. Most of the weeks in Ambie bahar during fruit development period have negligible amount of rainfall which is good for quality point of view, but during fruit maturity period there was a greater amount of rainfall observed. Most of the weeks in Mrig bahar during flowering period have surplus rainfall and there after it very less during fruit development and maturity which is best combination for quality of fruits. Therefore, in general, it can be concluded that supplemental irrigation requirement in Mrigmbahar was maximum followed by Hast and Ambiebahar.

- KEY WORDS : Water balance, Pomegranate, Meteorological data

- HOW TO CITE THIS PAPER : Shinde, R.V., Jadhav, S.B. and Pawar, S.N. (2016). Water balance for pomegranate based on meteorological data . Internat. J. Agric. Engg., 9(1) : 86-93. 